\title{
Evaluation of Rapid Detection Kit against Avian Influenza A Virus and H5 Subtype for Field Sample
}

\author{
Michael Haryadi Wibowo ${ }^{1,{ }^{*}}$, Tri Untari ${ }^{1}$, Sidna Artanto ${ }^{1}$, Krisdiana Putri $^{2}$, \\ Surya Amanu ${ }^{1}$, Widya Asmara ${ }^{1}$
}

\author{
${ }^{1}$ Department of Microbiology, Faculty of Veterinary Medicine, Universitas Gadjah Mada, \\ Yogyakarta 55281, Indonesia \\ ${ }^{2}$ Department of Public Health, Faculty of Veterinary Medicine, Universitas Gadjah Mada, \\ Yogyakarta 55281, Indonesia
}

\begin{abstract}
Avian influenza virus is a poultry viral disease, which causes high economic losses. Various efforts have been made to control the disease. One effort required fast and accurate screening diagnostic test. This study aimed to determine the potential of a rapid test kit, namely AIV/H5 Anigen Rapid Test for the detection of AI virus types A and subtype H5 in the fields. Some tests were carried out, e.g. the potential test, cross-reaction test, sensitivity and specificity test. The potential test was done to evaluate detection limits of the kit, by having the test of a serial dilution of AI virus positive control. Cross-reaction test was done to detect antigens other than AI virus H5N1, e.g. IB virus of Massachusetts strain, IBV strain 4-91, Newcastle Disease virus, and Escherichia coli. Sensitivity and specificity test were applied to the field samples which clinically and laboratory were confirmed as $\mathrm{H} 5 \mathrm{~N} 1$ positive. To confirm the result of rapid test was then being done by reverse transcriptase polymerase chain reaction. Based on these results it can be concluded that Anigen Kit AIV/H5 Ag Rapid Test can detect antigen-containing samples having AI virus HA titer up to $2^{6}$ of type A virus, and up to $2^{5}$ for subtype $\mathrm{H} 5$ virus. Anigen Kit AIV/H5 Ag Rapid Test showed no cross-reactions with Infectious Bronchitis virus, Newcastle Disease virus, and Escherichia coli. Anigen A Rapid Test Kit AIV Ag showed a sensitivity of 50\% and specificity of 100\%, while Anigen Ag Rapid Test Kit AIV/H5 showed a sensitivity of 25\% and specificity of $100 \%$.
\end{abstract}

Keywords: Avian influenza, rapid detection kit, specificity and sensitivity

\section{Introduction}

Highly pathogenic avian influenza (AI) H5N1 subtype has been firstly reported to cause the mortality of commercial poultry farms in West Java and Central Java in 2003 (Asmara et al., 2005; Damayanti et al., 2004; Dharmayanti et al., 2004; Wiyono et al., 2004; Wibowo et al., 2007). The outbreak was continued to spread to other provinces and it has been declared to be endemic of AI infection in all provinces except Maluku and Gorontalo provinces (NCAIPIP, 2008). In the

\footnotetext{
*Corresponding author:

Michael Haryadi Wibowo

Department of Microbiology, Faculty of Veterinary Medicine, Universitas Gadjah Mada, Yogyakarta 55281, Indonesia

E-mail:mhwibowo@ugm.ac.id.
}

year of 2011, AI outbreaks had been reported in Gorontalo, where previously known as free AI cases. The AI infection is still existing sporadically throughout Indonesia, as reported by Wibawa et al. (2012), Hidayanto et al. (2015), and Mahardika et al. (2016). A further report of $\mathrm{H} 5 \mathrm{~N} 1$ virus in Indonesia still belong to HPAI virus (Wibowo et al., 2006; Dharmayanti and Indriani, 2007; Wibowo et al., 2013; Srihanto et al., 2015; Susanti et al., 2008).

Avian influenza virus is a member of the family Orthomyxoviridae, genus Influenza $A$ virus. The viral genome is segmented and consists of single-stranded-RNA, negative sense, and has eight segments gene which responsible for internal and surface proteins. The surface protein consists of hemagglutinin $(\mathrm{H} / \mathrm{HA})$, neuraminidase (N/NA), and matrix 
(M2). Internal proteins are nucleoprotein (NP), polymerase complex (PB1, PB2, PA), matrix (M1), NS-1, and NS-2. Influenza A virus is classified into type $A, B$, and $C$ based on matrix or nucleoprotein antigenic character. Influenza viruses A are further divided into subtypes based on the antigenicity of protein $\mathrm{H} / \mathrm{HA}$ and N/NA (Cox and Kawaoka, 1998). The cumulative studies reported that $16 \mathrm{HA}$ and 9 NA subtypes had been recognized (Fourchier et al., 2005). A putative $17^{\text {th }}$ HA was recently discovered from fruit bat (Tong et al., 2012). Avian influenza virus $\mathrm{H} 5 \mathrm{~N} 1$ subtype has a broad range of hospes, including: variety of avian species (Anonymous, 2003), dogs and cats (Songserm et al., 2006), exotic animals such as leopard and tiger (Kheawacharoen et al., 2004), and humans (Gambaryan et al., 2005).

The outbreak of the disease caused high economic losses due to morbidity and mortality of bird, eradication cost, and export-import restriction for poultry product. Various attempts have been made to control the disease. The diagnosis could be achieved by in vitro, in vivo, and molecular assay. Molecular diagnosis is the direct detection at the molecular level or nucleic acid genome contained in the sample. Some of the advantages of modern diagnostic techniques are: fast, accurate, sensitive and specific, but requires a more expensive and specific equipment, technically complicated, and standardized reagents (Charlton et al., 2009; Suarez, 2003). One of the control strategies required rapid and precise diagnosis. In the field, the condition of diagnosis could not be performed accurately, due to some constraints. Common field diagnosis is screening to have a quick response. However; the result should be followed by definite laboratory testing.

Rapid test kit has been developed, based on immunochromatography assay. The kit uses cellulose membrane as a carrier and colloidal gold-labeled antibody as a tracer. This method has been widely used as a diagnostic tool for infectious diseases in humans and animals, as well as for detection of bioactive molecules, hormones, and hapten. Kang et al. (2007) reported rapid immunochromatography method for detecting rabies virus. According to Peng et al. (2008), immunochromatography strip model has been used for the diagnosis of AI virus $\mathrm{H} 9$ subtype in poultry. Rapid test kit has some advantages especially it is easy to perform, does not need a special skill, can be used immediately in the field situation and possible to differentiate AI virus subtypes. According to Tsuda et al. (2007), the technique also could be used to detect the $\mathrm{H} 5$ subtype AI virus in poultry.

One of the AI diagnostic kits is Anigen AIV A/H5 Ag rapid test kit which produced for field AI detection, both A type and H5 subtypes applied directly from feces samples. Technically, the rapid test kit does not need special skills, test result could be observed in short time and could be applied directly to the field condition. This study aimed to evaluate the potential, sensitivity, and specificity of those diagnostic kits.

\section{Materials and Methods}

The materials were Anigen A/H5 Rapid AIV Ag test kit, RNA isolation kits, and reverse transcriptase-polymerase chain reaction (RT-PCR) kits. Cloacal swabs samples were obtained from chicken with symptoms to AI infection. Positive control of AI virus and Escherichia coli have been characterized by Department of Microbiology, Faculty of Veterinary Medicine, Universitas Gadjah Mada. Newcastle disease virus and Infectious Bronchitis virus were obtained from virus vaccine. Phosphate buffered saline (PBS) was used as negative control. Other materials were viral transport media, cloacal swab, and conical tube.

\section{Limit detection kits}

For analysis of the kit limit detection, positive control AI virus was used as the samples. Positive control of AI virus suspension was diluted in a serial manner, to reach following dilution: $2^{1}, 2^{2}, 2^{3}, 2^{4}, 2^{5}, 2^{6}, 2^{7}, 2^{8}$. Each dilution was tested with rapid test kits AIV/H5 Ag and confirmed by using RT-PCR. 


\section{Cross-reaction test}

To determine the possible reaction with other antigens in the poultry, rapid test kits were examined to the potential cross reaction with Newcastle Disease virus, Infectious Bronchitis virus, and E. coli. Each isolate was tested using the rapid test kit $\mathrm{AIV} / \mathrm{H} 5 \mathrm{Ag}$ according to the manufacturer's instructions and was performed with five repetitions.

\section{Field rapid test kits application}

The sample used to perform the test of Anigen $^{\mathrm{R}}$ rapid test kit AIV A was obtained from Lampung and Yogyakarta, Central Java. Samples taken from Lampung were cloacal swabs and organ samples where the cases had been positively confirmed by RT-PCR. Samples from Yogyakarta obtained from cases of AI at a poultry farm by the end of 2010 when this research was being conducted. The case was clinically characteristic to AI infection and already confirmed by RT-PCR. Cloacal swabs were collected at day 6 when the case was clinically observed.

A cloacal swabs samples of chickens with AI symptoms were tested with rapid test kits Anigen A/H5 AIV Ag according to manufacturer's instructions. Principally, the cloacal swab was added in the assay buffer, mixed thoroughly and allowing the debris to settle down in a few second. Using the disposable dropper provided by the kits, the supernatant was dropped onto the sample window of the slide provided and allowed to flow by capillary action of the horizontal surface along the chromatography strip. To confirm the result, we also used positive control virus of Indonesian isolate.

\section{Laboratory testing}

Sensitivity and specificity of rapid test kits Anigen A/H5 AIV Ag were determined by comparing the results of the rapid test of field sample with RT-PCR assay. Cloacal swab samples was placed in the conical tube filled with PBS, antibiotic, and antifungal. The mixtures were centrifuged, and the supernatant was collected and used for RNA isolation.

\section{RNA extraction}

Viral RNA was extracted from the supernatant of cloacal swab using RNA extraction kit Invitrogen Pure Link ${ }^{\mathrm{TM}}$ Micro to Midi 50xRxn Total RNA Purification System according to the manufacturer's protocol. To purify total RNA from $0.2 \mathrm{ml}$ supernatant of the cloacal swab, in a $1.5 \mathrm{ml}$ RNAse-free microcentrifuge tube was added $0.2 \mathrm{ml}$ of RNA lysis solution containing $1 \%(\mathrm{v} / \mathrm{v}) 2-$ mercaptoethanol. The mixture was vortexed thoroughly to disrupt and lyse blood cells and followed by a centrifugation at 12,000 $\mathrm{x}$ $\mathrm{g}$ for 2 minutes at room temperature. The supernatant was transferred to clean $1.5 \mathrm{ml}$ RNA-se free microcentrifuge tube and $200 \mu 1$ of $100 \%$ ethanol was added. Any precipitate was dispersed by vortexing or pipetting up and down several times. The sample was transferred to the RNA spin cartridge, centrifuged at $12,000 \times \mathrm{g}$ for 15 seconds at room temperature. The flow-through was discarded and $700 \mu \mathrm{l}$ of Wash Buffer I was added to the spin cartridge and centrifuged at $12,000 \times$ g for 15 seconds at room temperature. The spin cartridge was placed into a clean RNA Wash Tube and $500 \mu$ l of Wash Buffer II with ethanol was added to the spin cartridge then centrifuged at $12,000 \times$ for 15 seconds at room temperature. The flow-through was discarded. This step was repeated once. The spin cartridge was centrifuged at $12,000 \times \mathrm{g}$ for 1 minute at room temperature to dry the membrane, and the cartridge was moved into an RNA Recovery Tube. Fifty $\mu 1$ of RNAsefree water was added to elute the RNA and incubated for 1 minute at room temperature then centrifuged for 2 minutes at 12,000xg at room temperature. This step was repeated once, after that the cartridge was discarded and elutes was stored at $-4^{\circ} \mathrm{C}$.

\section{Thermocycling}

One step Reverse transcriptase-PCR (RT-PCR) was carried out in Gene Amp ${ }^{\circledR}$ PCR System 2400 machine and performed using Invitrogen Superscript ${ }^{\mathrm{TM}}$ III One-Step RT-PCR System. Primers designed for this research was for $\mathrm{H} 5$ and N1. The design for H5 was H5-F: 5'-ggagactcagcaatcccatgaaaag- 
$3^{\prime}$ and H5-R: 5'-ccataccaaccgtctaccattcc-3', which has $246 \mathrm{bp}$ expected product size (Ito et al., 2001). Meanwhile, N1 identification used a primer designed by Payungporn et al., (2004), which has nucleotide sequence: NAF: 5'-gtttgagtctgttgcttggtc-3' and NA-F: 5' tgatagtgtctgttattatgcc- $3^{\prime}$ which has $131 \mathrm{bp}$ expected band. The PCR condition for H5 and $\mathrm{N} 1$ were initially done with a reverse transcription step at $50^{\circ} \mathrm{C}$ for 30 minutes. After a hot start step at $94^{\circ} \mathrm{C}$ for 5 minutes, amplification was performed as follows: denaturation $\left(94^{\circ} \mathrm{C}\right.$ for 30 seconds), annealing $\left(50^{\circ} \mathrm{C}\right.$ for 1 minute for $\mathrm{HA}, 47^{\circ} \mathrm{C}$ minute for $\mathrm{NA})$ and extension $\left(68^{\circ} \mathrm{C}\right.$ for 45 seconds), ended by final extension at $68^{\circ} \mathrm{C}$ for 5 minutes. Total cycles performed in PCR were 40 times for HA, and 35 times for NA.

\section{Electrophoresis of PCR Product}

PCR products were run for electrophoresis in 1.5\% agarose gel in 1x TBE. Electrophoresis tank used MSMIDIDUO, Cleaver Scientific Ltd. The gel and was run at $100 \mathrm{~V}$ for 40 minutes. The gel was exposed under UV transilluminator at $302 \mathrm{~nm}$ wave length to check the result and then followed by determining the size of PCR product fragment by comparing the PCR products with the ladder.

\section{Determine of sensitivity and specificity}

Sensitivity and specificity test were analyzed by using a 2X2 table (Martin et al., 1988) and comparing the result of the rapid test with RT-PCR assay.

\section{Results and Discussion}

\section{The potency of Anigen rapid tests as detection kits}

The potency of Anigen rapid test kit AIV A/H5 Ag to detect AI antigen were evaluated by serial dilution of AI virus positive control which has been characterized in the Microbiology Laboratory. A positive result was observed a band line appear both in the test sample (T) and control zone (C) (Figure 1). However, the sample is considered negative if only one line band appears in the control zone (C) of the membrane (Figure 1).
The results showed that Anigen ${ }^{\mathrm{R}}$ rapid test kit AIVA Ag is capable of detecting AI virus type $A$ antigen up to $2^{6}$ dilutions. This is equivalent to HA titers $2^{4}$ with a reaction time less than 20 minutes. Anigen ${ }^{\mathrm{R}}$ rapid $\mathrm{H} 5$ AIV Ag test kit exhibited potential detection of $\mathrm{H} 5$ subtypes antigen up to dilution $2^{5}$, equivalent to HA titer of $2^{5}$ with a reaction time less than 20 minutes. The results showed different results if compared to other rapid tests, such as Vet. Smart AIV kit (manufactured by Pacific Biotech Co. Ltd.). This rapid test reported in Thailand by using Thailand AI virus isolates demonstrated that the potential detection of the kits against AI virus H5N1 subtype up to $10^{7} \mathrm{ELD}_{-50} / \mathrm{ml}$ (Tantilertcharoen et al., 2016).
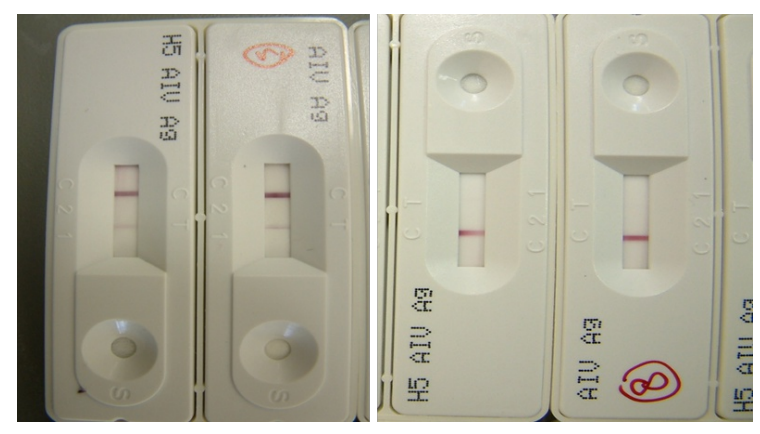

Figure 1. Rapid test positive (code5) and negative (code 8).

\section{Cross-reaction test}

To determine cross-reactions to other pathogens in chicken, the kits were tested to ND virus, IB virus, and Escherichia coli. The test was performed in five repetitions for each virus and bacterium. The results indicated that the kit showed no crossreaction to those pathogens. This result is similar to Tsuda et al. (2007), who developed an immunochromatographic kit for rapid diagnosis of $\mathrm{H} 5$ avian influenza virus infection. In that study, cross-reaction of the kit was evaluated against avian Paramyxovirus, Infectious Brochitis virus, and other viruses but also against Staphylococcus sp.

\section{Sensitivity and specificity of the test}

Samples of rapid test kits for typing and subtyping were obtained from cases of AI infection, which clinically characteristic to AI infection and already confirmed by RT- 
PCR assay. The number of positive and negative by rapid test antigen detection and RT-PCR on the same group of the sample are shown in Table 1 and 2. Sensitivity test was calculated by Martin et al. (1988) presented in a $2 \times 2$ table.

Table 1. Anigen Rapid Test kit AIV AAg vs RT PCR (for typing).

\begin{tabular}{lccc}
\hline & $\begin{array}{c}\text { RT-PCR } \\
\text { positive }\end{array}$ & $\begin{array}{c}\text { RT-PCR } \\
\text { negative }\end{array}$ & Total \\
\hline Rapid positive & 5 & 0 & 5 \\
Rapid negative & 5 & 7 & 12 \\
Total & 10 & 7 & 17 \\
\hline
\end{tabular}

Typing calculation of sensitivity was $5 / 10$ $=50 \%$, while the specificity was $7 / 7=$ $100 \%$.

Table 2. Anigen Rapid Test kit AIV H5Ag vs RT PCR (for subtyping).

\begin{tabular}{lccc}
\hline & $\begin{array}{c}\text { RT-PCR } \\
\text { positive }\end{array}$ & $\begin{array}{c}\text { RT-PCR } \\
\text { negative }\end{array}$ & Total \\
\hline Rapid positive & 7 & 0 & 7 \\
Rapid negative & 21 & 3 & 24 \\
Total & 28 & 3 & 31 \\
\hline
\end{tabular}

Subtyping calculation of sensitivity was $7 / 28=25 \%$, while the specificity was $3 / 2$ $=100 \%$.

Sensitivity test for AI typing kit by the Anigen A Rapid Test kit AIV Ag showed better results compared to AI subtyping kit by Anigen Rapid Test kit AIV H5 Ag. The value of sensitivity was $50 \%$ and $25 \%$ respectively. Rapid test specificity both typing and subtyping indicated higher results $(100 \%)$ compared to sensitivity test. Sensitivity and specificity test which was conducted by AI reference laboratory in Geelong, Australia, reported that various rapid test kits indicated similar results to our study (Sellect, pers. comm.).

The results of this study showed that the subtyping sensitivity was low (25\%) compared to the similar research on rapid tests which have been conducted in Indonesia by Loth et al. (2008). It was reported that the detection kit Anigen AIV rapid test kit had a higher sensitivity of $69 \%$. Rapid detection test of Flu DetectTM capture antigen test kit had a sensitivity of $71 \%$. According to Boland et al. (2006) and the report was cited by Loth et al. (2008) stated that Anigen sensitivity reached $76 \%$, for field application where samples obtained from AI infected chickens in Indonesia. Another study conducted by Chua et al. (2007) showed that the sensitivity of the 5 types of rapid detection test kits for AI (brand-name not specified) generally showed similar results which ranges from $36.3 \%$ to $51.4 \%$. According to that study, the result was more variable depending on the type of sample. Fecal sample indicated sensitivity value of $0 \%$ to $12.5 \%$, while the cloacal swab samples were $31.5 \%$ to $47.5 \%$. Pulmonary organ sample exhibited varied sensitivity results, ranges $34.4 \%$ to $81.3 \%$, while the swab brain reaches 40 to $93.3 \%$ of sensitivity.

Specificity test calculation according the Martin's table showed that the test indicated very good result, reaching $100 \%$. The results are relevance to the report of Loth et al. (2008) that specificity of rapid AIV Anigen ${ }^{\mathrm{R}}$ reaches $98 \%$. According to the study of others rapid test kit that was Flu Detect ${ }^{\mathrm{TM}}$ strip antigen capture test has similar sensitivity of $98 \%$. Specificity tests of the rapid test conducted in Indonesia applied to sample obtained from AI infected chicken reported by Boland et al. (2006) cited by Loth et al. (2008) was reached $97 \%$.

Analysis for some possible causes of the low sensitivity of the rapid test has been reported by Chua et al. (2002), stated that the result of the rapid test kit depending on the type of sample. According to that study, feces samples showed the lowest specificity, while cloacal samples exhibited various specificity, ranged from $31.5 \%$ to $49.4 \%$. The best specificity obtained from brain swab ranging from 40 to $93.3 \%$, especially in the case of died birds with symptoms of encephalitis. Specimens from chicken origin showed the sensitivity varies between $37.6 \%$ to $60.6 \%$, while samples from the dead waterfowl were varies ranges from $30.7 \%$ to $49.2 \%$.

Basically, the sensitivity of antigen detection kits depending on the concentration of virus in the sample. The concentration of 
antigen is mainly correlated with the titer of virus in the sample. Artificial infection of H5N1 virus in ducks showed replication occurs in a few days at the beginning of infection. However, viral titers generally are found in the trachea and cloaca of chicken higher than the duck (Chua et al. 2008). According to Loth et al. (2008) type of sample for the application of rapid test kit should be taken into consideration, particularly it should be obtained from the sick birds or birds that had just died due to AI virus infection. In principle, there should be enough virus titer in a sample for rapid positive results. Additionally, cloaca swab samples should be taken without any fecal, mucus, and blood contamination, due to the potential interference of the rapid test kit process (Loth et al., 2008; Tsuda et al., 2008). Interesting report from Yamammoto et al. (2008) suggested that feathers can be considered useful samples for early AI virus detection in duck. The reason is that larger amounts of AI viruses can be isolated for a longer time from feathers than from swabs.

Further analysis of low sensitivity in this study, it may due to the AI virus master seed which be used to produce antibodies in the producing country is different with AI virus circulating in Indonesia. Smith et al. (2006) and Chen et al. (2006) analyzed that there are three genetically distinct subpopulations of AI viruses in Indonesia and distributed in several different geographic areas, although all type the AI virus can be found on the island of Java. The difference means that AI viruses Indonesia origin have antigenic variation, which can be measured from antibodies titer difference from each sub-population (Smith et al., 2006).

\section{Conclusions}

Based on these results, it could be concluded that Anigen Rapid Test Kid AIV/H5 $\mathrm{Ag}$ are able to detect $\mathrm{AI}$ antigen-containing samples having HA titer up to $2^{6}$ to determine type A AI virus and HA titer up to $2^{5}$ for $\mathrm{H} 5$ subtype detection. Anigen Rapid Test Kit AIV/H5 Ag showed no cross-reactions with Infectious Bronchitis virus, Newcastle disease and Escherichia coli. Sensitivity of Anigen A Rapid Test Kit AIV Ag was 50\% and specificity test was 100\%, while Anigen Ag Rapid Test Kit AIV/H5 showed a sensitivity test of $25 \%$ and a specificity of $100 \%$.

\section{Acknowledgments}

Sincerely thank to Drh. M. Munawaroh MM. who allowed the data to be published and the management of PT. Mega Medika Mandiri, which supported this research.

\section{References}

Anonymous, 2003. Avian Influenza. Preliminary Final Report/OIE Terrestrial Animal Health Standards Commission. Appendix. pp. 7-11.

Asmara, W., Wibowo, M.H., Tabbu C.R. 2005. Hemagglutini Subtype Identification of Avian Influenza Virus Isolated from Various Species of Birds Using RT-PCR. Sain. Vet. J.,: 42-45.

Charlton, B., Crossley, B., Hietala, S. 2009. Conventional and Future Diagnostics for Avian Influenza. Comp. Immunol. Microbiol. and Infect., 32, 341-350.

Chen, H., Smith, G.J.D., Li, K.S., Wang, J., Fan, X. H., Rayner, M.J., Vijaykrishna, D., Zhang, J.X., Zhang, L.J., Guo, C.T., Cheung, C. L., Xu, K.M., Duan, L., Huang, K., Qin, K., Leung, Y.H.C., Wu, W.L., Lu, H.R., Chen, Y., Xia, N.S., Naipospos, T.S.P., Yuen, K.Y., Hassan, S.S., Bahri, S., Nguyen, T.D., Webster, R.G., Peiris, J.S.M., Guan, Y. 2006. Establishment of Multiple Sub lineages of H5N1 Influenza Virus in Asia: Implication for Pandemic Control. Proc. Nat. Aca. Sci., 103(8), 2845-2850.

Chua, T-H., Ellis, T.M., Wong, C.W., Guan, Y., Ge, S.X., Peng, G., Lamichane, C., Maliadis, C., Tan, S-W., Selleck, P., Parkinson, J. 2007. Performance Evaluation of Five Detection Test for Avian Influenza Antigen with Various Avian Sample. Avian Dis., 56, 96-105.

Cox, N.J., Kawaoka, Y. (1998) Orthomyxoviruses: Influenza. In: Microbiology and Microbial infection. Ed Collier, L., Ballows, A. and Sussman, M. Vol.1: Virology, Oxford University 
press, Inc. New York. pp. 386-433.

Damayanti, R., Dharmayanti, N.L.P.I., Indriani, R., Wiyono, A., Darminto. 2004. The Clinico-pathological Effect of Chicken Infected with Highly Pathogenic Avian Influenza in Some Farms in East Java and West Java. JITV, 9(2), 128-135.

Dharmayanti, N.L.P.I, Damayanti, R., Wiyono, A., Indriyani, R., Darminto. 2004. Identification of Avian Influenza Virus of Indonesian Isolate by Reverse Transcriptase Polymerase Chain Reaction. JITV, 9(2), 136-143.

Dharmayanti, N.L.P.I., Indriyani R. 2007. Molecular Pathogenicity of Avian Influenza Virus Isolated in the Year 2005. Media Kedokteran Hewan, 23(2), 68-73.

Fouchier, R.A.M., Munster, V., Waltensen, A., Besterbroer, T.M., Herfst, S., Swith, D., Rimnelzwaan, G.F., Olsen, B., Osterhaus, A.D.M.E. 2005. Characterization of Novel Influenza A Virus Hemagglutinin Subtype (H16) Obtained from Black Headed Gulls. J. Virol., 79(5), 2814-2822.

Gambaryan, A., Tuzikov, A., Pazynina, G., Bovine, N., Balish, A., Klimov, A. 2005. Evolution of the receptor binding phenotype of influenza A (H5) viruses. Virology, 344, 432:438.

Hidayanto, N.K., Asmara, W., Wibowo, M.H. 2015. Characterization of Avian Influenza Virus H5N1 Subtype of Non Structural Gene from Duck Isolated in 2013. Sain. Vet. J., 33(2), 195-204.

Ito, I., Goto, H., Yamamoto, E., Tanaka, H., Takeuchi, M., Kuwayama, M., Kawaoka, Y., Otsuki, K. 2001. Generation of HPAI A Virus from an Avirulent Field Isolate by Passaging in Chicken. J. Virol. 75., (9), 4439-4443.

Kang, B., Oh, J., Lee, C., Park, B., Park, Y., Hong, K., Lee, K., Cho, B., Song, D. 2007. Evaluation of a Rapid Immunodiagnostic Test Kit for Rabies Virus. J. Vir. Method., 145, 30-36.

Khewcharoen, J., Oraveerakul, K., Kuiken,
T., Fourchier, R.A., Amonsin, A., Payungporn, S. 2004. An Avian Influenza H5N1 in Tiger and Leopard. Emerg. Infect. Dis., 10, 2189-2191.

Loth, L., Prijono, W.B., Wibawa, H., Usman, T.B. 2008. Evaluation of Two Avian Influenza Type A Rapid Antigen Tests Under Indonesian Field Conditions. Diagn. Invest., 20, 642-644.

Mahardika, G.N., Jonas, M., Murwijati, T., Fitria, N., Suartha, I.N., Suartini, I.G.A.A., Wibawan, I.W.T. 2016. Molecular Analysis of Hemmagglutinin-1 Fragment of Avian Influenza H5N1 Viruses Isolated from Chicken Farms in Indonesia from 2008 to 2010. Vet. Microbiol., 186, 52-58.

Martin S.W., Meek A.H., and Willeberg P. (1988) Sensitivity and Specificity. In Veterinary Epidemiology Principles and Methods. Iowa State University Press. pp. 63-66.

National Committee for Avian Influenza and Preparedness of Influenza Pandemic (NCAIPIP). 2008. The Timeline Data of Avian Influenza Outbreak in Indonesia. http//www.komnasfbpi.go.id/situati on/update.html.

Payungporrn S., Piraya P., Salin C., Apiradee T., Juthatip K., Kanisak O.V., Alongkorn A., Yong P. 2004. SingleStep Multiplex Reverse TranscriptasePolymerase Chain Reaction for Influenza A Virus Subtype H5N1 Detection. Viral Imm., 17, 588-593.

Peng F., Wang Z., Zhang S.,Wu R., Hu S., Li Z., Wang X., Bi D. 2008. Development of an Immunochromatographic Strip For Rapid Detection of H9 Subtype Avian Influenza Viruses. J. Clin. Vaccine Immunol., 15(3), 569-574.

Smith G.J.D., Naipospos T.S.P., Nguyen T.D., de Jong M.D., Vijaykrishna D., Usman T.B., Hassan S.S., Nguyen T.V., Dao T.V., Bui N.A., Leung Y.H. C., Cheung C.L., Rayner J.M., Zhang J.X., Poon L.L. M., Li K.S., Nguyen V.C., Hien T.T., Farrar J., Webster R.G., Chen H., Peiris J.S.M., Guan Y. 2006. Evolution and 
Adaptation of H5N1 Influenza Virus in Avian and Human Hosts in Indonesia and Vietnam. Virol., 350, 258268.

Sellect P., Avian Influenza Rapid Test Field Trial Data. Australian Animal Health Laboratory, Geelong, Australia. Unpublished data.

Songserm T., Alongkorn A., Rungroj J., Namdee S.H., Noppodal M., Nuananong P., Sunchai, P. 2006. Avian Influenza H5N1 in Naturally infected Domestic Cat. Emerg. Infect. Dis., 12(11), 1744-1764.

Srihanto E.A., Asmara W., Wibowo M.H. 2015. Philogenetic Molecular and Antigenic Structure Analysis of Avian Influenza Virus of Subtype H5N1 Lampung Isolates Collected during 2008 to 2013. Jurnal Kedokteran Hewan, 9(1), 83-88.

Suarez D.L. 2003. Moecular Diagnostic Techniques: Can We Identify Influenza Viruses, Differentiate Subtype and Determine Pathogenicity Potential of Viruses by RT-PCR. Avian Dis., 47, 318325.

Susanti R., Soejoedono R.D., Mahardika I.G.N.K., Wibawan I.W.T., Suhartono M.T. 2008. Molecular Analysis of Hemagglutinin Gene of HPAI of H5N1 Subtype Isolated from Waterfowl. JITV, 13(3), 229-239.

Tantilertcharoen R., Prapasakul N., Thanawongnuwes R., Kramomthong I. 2016. Performance Evaluation of Avian Influenza Virus Antigen Rapid Test Kit. Veterinary Diagnostic Laboratory Unit, Faculty of Veterinary Science, Chulalongkorn University, Bangkok 10330.

Tong S., Li Y., Rivailler P., Christina C., Danilo A., Castillo A., Chen L.M., Recuenco S., Ellison J.A., David C.T., York I.A., Turmelle A.S., Moran D., Rogers S., Shi M., Tao Y., Weil M.R., Tong K., Rowe L.A., Sammons S., Xu X., Frace M., Lindblade K.A., Cox N.J., Anderson L.J., Rupprecht C.E., Donis O. 2012. A Distinct Lineage Influenza A Virus from Bats. Proc. Nat. Aca. Sci., 109, 4269-4274.

Tsuda H., Sakoda Y., Sakabe S., Mochizuki T., Namba Y., Kida H. 2007. Development of an Immunochromatographic Kit for Rapid Diagnosis of H5 Avian Influenza Virus. Infection. J. Microbiol. Immunol., 51(9), 903-907.

Wibawa H., Prijono W.B., Dharmayanti N.L.P.I., Irianingsih S.H., Miswati Y., Rohmah A., Andesyha E., Romlah, Daulay R.S.D., Safitria K. 2012. Outbreak investigation of Duck Disease in Central Java Province, Yogyakarta Special Province, and East Java Province: Identification of New Clade of Avian Influenza Virus H5N1 Subtype in Indonesia. Buletin Laboratorium Veteriner ,12(4), 1-9.

Wibowo H.W., Susetya H., Untari T., Putri K., Tabbu C.R., Asmara W. 2006. Molecular Study on the Pathogenicity of Avian Influenza Virus. Indones. J. Biotechnol., 11(2), 901-907.

Wibowo M.H., Susetya H., Untari T., Wahyuni A.E.T.H., Tabbu C.R., Asmara W. 2007. Molecular Identification of Avian Influenza Virus from Cases Both with and without Symptom Specific for Avian Influenza. J. Vet., 8(3), 103110.

Wibowo M.H., Srihanto E.A., Putri K., Asmara W., Tabbu C.R. 2013. The Development of Pathogenicity of Avian Influenza Virus Isolated from Indonesia. Indones. J. Biotechnol., 18(2), 133-143.

Yamamoto Y., Nakamura K., Okamatsu M., Miyazaki A., Yamada M., Mase M. 2008. Detecting Avian Influenza Virus (H5N1) in Domestic Duck Feathers. Emerg. Infect. Dis., 14(10), 1671-1672.

Wiyono A., Indriani R., Dharmayanti N.L.P.I., Damayanti R., Parede L., Syafriati T., Darminto. 2004. Isolation and Characterization of HPAI virus $\mathrm{H} 5$ Subtype of Chicken from Outbreak in Indonesia. JITV, 9(1), 61-71. 